DOI: 10.2478/atd-2020-0005

\title{
Quality of Life and Value Orientation of University Students in Middle-Adulthood
}

\author{
Slávka Čepelová - Silvia Barnová ${ }^{*}$ \\ Received: January 9, 2020; received in revised form: February 27, 2020; \\ accepted: March 4, 2020
}

\begin{abstract}
:
Introduction: Every person needs to define their own parameters of values and quality of life as there is a range of life circumstances and objective or subjective factors which force individuals to make decisions and select from available solutions depending on their personalities and other determinants. Currently, these notions have been broadly discussed and the authors of the presented study believe, that in the context of value orientation and life quality, there are new interactions, correlations and new truth to be revealed.

Methods: The presented research aimed to find out about the respondents' perception of their quality of life and value orientation using WHOQOLBREF 1996 questionnaire and Vonkomer's HO-PO-MO questionnaire and unrevealing the relations between them. The research sample consisted of 300 in their middle-adulthood involved in external university study programs.

Results: The results presented in this study indicate that from the aspect of the subjective perception of the quality of life by individuals, external factors such as age or place of residence are not decisive. The most important finding of the research is that, as well as value orientation focusing on the values of knowledge, education and economic aspects leads to a better quality of life; a better quality of life is determined by a value orientation focused on the fields of knowledge, education and economic values.

Discussion: The attention of professionals from various fields of science and their research activities is given mostly to the relatively small population of young generation, the process of the creation of their value orientation and thus, their subjective quality of life. The presented study is focused on productive generation of middle-aged adults involved in tertiary education, which has experienced several massive changes in the society and received primary and secondary education in an educational context different from the present situation.
\end{abstract}

Slávka Čepelová, DTI University, Department of School Pedagogy and Psychology, Dubnica nad Váhom, Slovakia; cepelova@dti.sk

Silvia Barnová, DTI University, Department of School Pedagogy and Psychology, Dubnica nad Váhom, Slovakia; barnova@dti.sk 


\title{
Acta Educationis Generalis \\ Volume 10, 2020, Issue 1
}

\begin{abstract}
Limitations: The conducted research into the respondents' quality of life is limited by the applied methods as it focuses on four basic areas of quality of life and quantitative methods are used. The advantages of this approach lie in exactly defined fields and quantitative data which enable comparison. One of its shortcomings is that it does not find out anything about the qualitative, dynamic aspects of the respondents' reflections about their own quality of life.

Conclusion: The findings show that quality of mental life correlates with educational value orientation as well as quality of social relationships with social value orientation. It can be stated that, as well as value orientation focusing on the values of knowledge, education and economic aspects leads to a better quality of life; a better quality of life is determined by a value orientation focused on the fields of knowledge, education and economic values.
\end{abstract}

Key words: quality of life, values, value orientation.

\section{Introduction}

Following a thorough literature review, it can be assumed that values and quality of life are among the frequently discussed issues both by professional and lay public and so, acquire a multidimensional and interdisciplinary character (Krásna, 2014). There has been done a lot of research on the relations between these two phenomena and, e.g. Rokeach's (1979) findings proved that values are an important indicator of quality of life.

It is indisputable that individuals need to define their own parameters of values and life quality as there is a range of life circumstances and objective or subjective factors which force individuals to make decisions and select from available solutions depending on their personalities and other determinants. The choices and decisions people must make throughout their lives contribute to finding their sense of life, which is closely connected with the determination of values and value orientation in these individuals. As stated by Kováč (2007), the sense of life is among the important components of quality of life. Moreover, he considers the sense of life a broad spectral principle of quality of life. Therefore, it is important to improve the quality of life by means of the development of positive and socially acceptable values. Moreover, it must be considered that individuals' sense of life is reflected in values.

During the last decades, especially in the developed countries, it has come to certain changes in the value orientation of people, as well as in the parameters of quality of life in the context of the changing social reality. So, it is evident that value orientation and quality of life are not stable characteristics (Vomáčková, 2015). The perceived quality of life changes throughout individuals' lives because people modify their values, attitudes and opinions regarding happiness, satisfaction or health depending on the circumstances, time and their experience. 


\section{Acta Educationis Generalis \\ Volume 10, 2020, Issue 1}

For example, in the case of health issues, people tend to appreciate health most; or when exposed to stressful situations or harsh circumstances at home, in school or at work, well-being represents a high value. As for values, we prefer those spheres of life in which we have problems or the things we miss. Based on the above, we can state that the perception of quality of life is influenced by many occurring situations, and its evaluation is determined by factors such as age, personality traits, gender, system of values, coping with negative phenomena, etc.

\section{Values and value orientation}

Values represent an interdisciplinary notion which is studied by professionals from many fields of science. It is dealt with by philosophy, pedagogy, sociology, ethics, or psychology, but it is often used in everyday life by lay public as well. Most axiologists assign a value to everything which satisfies people, what people consider necessary, useful, what they try to achieve, or what they appreciate. Kučerová (1996) accentuates that while objects and phenomena can exist without a subject, values are dependent on its existence as they become values only if they can satisfy - or dissatisfy - its needs. Values arise in the mutual relationship between the quality of an object and the quality of the evaluating subject.

Certain values can be assigned not only to individuals, but also to social groups. Social values are accentuated as they allow higher and broader social units to integrate. The vision of integrated Europe is linked to value tolerance and diversity, and protection of cultural and national identities - even of small ethnic groups.

Values represent one of the most important components of individuals' mental development, mental maturity and mental health (see e.g. Mehešová, 2017). They play an important formative role in personality development and take part in the organization of personality structure. Participation in creating values and experiences related to them deepen and widen individuals' life satisfaction, regulate their perception of and attitudes to success and loss, and also creates the basis for human sense.

In Slovak scholarly literature, value orientation is often terminologically operationalized based on the work of Grác (1979), which is still used as the starting point for many empirical studies on value orientation. He defines value orientation as the way how and why certain phenomena and objects are reflected in individuals' values and systems of values navigating human behaviour in a certain direction. Based on available resources (see also Salbot \& Kačáni, 2007; Brožík, 2004), it can be assumed that value orientation represents the tendency to prefer certain values to other ones and, at the same time, it is a continuous and stable system of values which regulates individuals' behaviour.

Theoretical value orientation can be characterized as placing emphasis on searching the truth by means of empirical, critical and rational approaches. At 


\section{Acta Educationis Generalis \\ Volume 10, 2020, Issue 1}

this level, people usually know what to do; they can give advice to others, but cannot help themselves because it is much easier to evaluate other people's behaviour. In the case of others, the occurring problems are much clearer, more visible and there is a range of solutions for them as we can observe them from the outside and keep distance. Theoretically, everything can be easily explained and also appropriate behaviour is precisely defined.

Practical value orientation accentuates the practical application of values in the real life with a focus on their persistence. In this case, theory is neglected as being strictly bound by various regulations, rules or principles can become an obstacle in achieving goals.

A particular value orientation is not purely the result of a combination of personality traits, but it is affected by a person's mental activities, too. Value orientation is a factor having a significant impact on individuals' manifestations. In individuals' values, the values of their social environments are reflected, as well as the gained life experiences, lifestyle, and the value orientation of their social class, social groups that they have ever belonged to, and people, who they appreciate and who represent authorities, role models, for them, etc. Value orientation as a hierarchy of values and the existing relations among them are decisive from the aspect of a person's individuality, maturity and integrity.

Values are not unalterable, they change in time and they are influenced by a rage of external factors. Value orientation is strongly influenced by long-term education in families and other social institutions, as well as by self-education. It is generally accepted that the primary role in the formation of a person's values and value orientation is played by two institutions - family and school. Families contribute to the formation of individuals' values and value orientation by means of family education/uprbringing. In the process of value orientation formation, education becomes the regulative force, but also a mediator of experiences focusing on the development of independent, responsible and socialized individuals. Schools attempt to achieve this goal by means of school education.

There is a general consensus regarding such values as humanism, democracy, human rights and freedoms, people usually tolerate but do not share values which contradict them. Eyre and Eyre (2000) - according to whom happiness of individuals depends on their value preferences - tried to define the "universal" values, which should form the basis for upbringing and education. They claim that broadly respected and universally acceptable values are beneficial not only for individuals sharing them, but also for those who they approach and who they treat in the spirit of these values. The above authors divided universal values into two groups - "values of being" (who we are) and values of giving (what we are giving to others). In the first one, honesty, courage, peaceability, self-reliance and potential, self-discipline and moderation, fidelity and chastity are included. In the second one, there are loyalty and dependability, respect, love, unselfishness and sensitivity, kindness and friendliness, justice and mercy. A 


\section{Acta Educationis Generalis \\ Volume 10, 2020, Issue 1}

positive correlation between values and happiness was observed by Schwartz (1992) as well.

\section{Quality of life}

As the notion of quality is broadly discussed from many aspects in a range of contexts at the society-wide level - quality of social life, quality of air, quality of products, quality of production, quality of management, etc. - the need for the definition of the quality of life arises. During the process of quality assessment, its relations with a variety of phenomena and circumstances must be considered. In general, quality represents an assigned value expressed on the scale from excellent to poor - it is a feature which distinguishes a phenomenon from another one - i.e. the life of a person from the life of another person (Křivohlavý, 2002). In his definition of quality of life, Krrivohlavý (2001) focuses on the extent of individuals' satisfaction with achieving their goals determining the direction of their lives. It means that if individuals work on the fulfilment of their goals and they can also achieve them, they evaluate their quality of life as better than less successful persons do. Similarly, Rosa (1999) defines quality as excellence, a kind of perfectionism, readiness and the ability to fulfil requirements, and to achieve goals.

Other authors, in their definitions, pay more attention to the link between the quality of life and happiness or well-being. Pelikán (1997) defines happiness as subjective experiencing of life satisfaction which can be characterized by repeated and intensive positive emotions.

According to the World Health Organization, quality of life is a multidimensional notion integrating subjective well-being. From this aspect, quality of life is a subjectively perceived life situation, related to a particular culture and in the context of the system of values in relation to individual goals, interests, expectations and assessment criteria.

Murgaš claims that an individual's quality of life consists of mental, somatic, religious, social and economic qualities, which lead to subjective well-being or happiness. These are confronted with health, social-pathological, economic and environmental issues in the external environment, which form a part of the current reality. The quality of "good" is understood as prosperity expressed by a sum of positive values - both of material and immaterial character. The quality of "bad" can be characterized as deprivation which represents a more progressive stage based on a long-term depression. It can be expressed as a sum of all the negative material and immaterial values. The above author further states that bi-polar scales are insufficient as life is not only "good" or "bad" and, therefore, aiming to express the complexity of quality of life, suggests to complete the scale from prosperity to deprivation by the value of human capital (Murgaš, 2007).

Hlásna (2006) defines quality of life as subjective experiencing of objective life circumstances, where not only what individuals experience is important, but also 


\section{Acta Educationis Generalis \\ Volume 10, 2020, Issue 1}

the factors having an impact on such experiencing, are decisive. A high degree of subjectivity is given by the particular personality type and life experience of the individual as individuality often prevails over general frameworks and conclusions of any kind.

As OECD (2011) research suggest, the quality of life can be measured by the following indicators:

1. quality of life and health status;

2. quality of life and work and life balance;

3. quality of life and education and skills;

4. quality of life and social connections;

5. quality of life and civic engagement and governance;

6. quality of life and environmental quality;

7. quality of life and personal security;

8. quality of life and subjective well-being.

Some of these indicators are reflected in Kostelnik's (2006) definition who claims that there is a link between the quality of human life and mental and physical health, with the ability to develop positive relationships with others, with the capacity to perceive beauty and enjoy it, and useful and successful work activities.

Based on the above definitions, the quality of life can also be understood as the expression of life happiness.

\section{Research goals}

The purpose of the presented research on value orientation can be seen in unrevealing trends in the current development. People cannot be perceived as passive individuals who, in the process of socialization, only uncritically take over their heritage and learn to accept biological and social norms and principles. Professionals should have in mind that values are based on emotional experiencing of the reality and needs and requirements represent will, volition and recognition of values.

The presented research aimed to find out about the respondents' perception of their quality of life and their value orientation by means of selected methods. The main goal was divided into two partial goals - to find out about the relations between variables on the side of respondents' quality of life and on the side of their value orientation and to carry out a comparative analysis of the above variables based on the age and residence of the respondents.

In our case, the carried out investigation into quality of life is limited by the applied methods as it focuses on four basic areas of quality of life and quantitative methods are used. The advantages of this approach lie in exactly defined fields and quantitative data which enable comparison. One of its shortcomings is that it does not find out anything about the qualitative, dynamic aspects of the reflections about the own quality of life by respondents. 


\section{Acta Educationis Generalis \\ Volume 10, 2020, Issue 1}

\section{Methods and research tools}

In the study, ex post facto research was used with the aim to learn about the respondents' opinions about the quality of their lives and their value preferences. Gathering information about their subjective perception of two important personality components - quality of life and value preferences - enables researchers not only to gain knowledge about their respondents' perception, but also to make comparisons and study the differences in the score distribution based on selected characteristics of the research sample.

As quantitative approach is the basic methodological paradigm of the presented research, its focus is on the issues of the relations between value orientation and quality of life by means of correlation calculations. In this study, not causality, the causes and effects of phenomena are investigated, but the tightness of their relationships expressed by correlation coefficients. Correlation coefficients do not answer the question whether a particular value orientation is the result of the quality of life, or the quality of life is significantly influenced by the individual's value orientation.

For investigating into the quality of life, the WHOQOL-BREF 1996 questionnaire was used, which was developed for the purposes of international comparative studies on inhabitants' health. It has been translated to more than 20 languages.

WHOQOL- BREF 1996 questionnaire consists of 26 items and its parts focus on 4 areas - physical quality of life (energy, tiredness, pain, discomfort, sleeping and resting); mental quality of life (physical well-being, positive and negative experiencing - feelings, emotions, self-evaluation, cognition, learning, memory, concentration); social relationships (interpersonal relationships, social support, sexual activity); and environment (financial security, freedom, safety and security, the quality of family and work environment, career opportunities, opportunities to gain new information, participation in social life, leisure, smoking, environment, mobility). In the questionnaire, the respondents indicate their subjective opinions, attitudes, and feelings. It means that the questionnaire does not work with objective data which can bring certain limitations.

The second research tool applied in the study is Vonkomer's (1991) HO-PO-MO questionnaire focusing on the issues of value orientation, attitudes towards values, and performance motivation. For the purposes of the presented research, only the first scale on value orientation was used. By means of this scale, information about individuals' educational, aesthetic, moral, economic and social orientation can be gathered. These fields are in accordance with Spranger's typology.

In the questionnaire, there are 11 real life situations and the respondents' task is to put the provided alternatives into order according to their preferences (on the scale from 5 points to 1 point).

There are four available variables in the field of quality of life and five variables of value orientation, so, a correlation matrix can be worked out, which helps to 


\section{Acta Educationis Generalis \\ Volume 10, 2020, Issue 1}

interpret mutual relations. As for quality of life, the scores achieved in physical, social, mental health and the perception, and the score for the perception of individuals' environments can be added up and the total score for the quality of life can be calculated. Unfortunately, this process cannot be realized.

\section{Research results}

\subsection{Quality of life}

As the gathered data show, a majority of the research participants have an average quality of life and only a small part of them evaluates it as poor. It can be assumed that as many as $36.8 \%$ of respondents' answers indicate a quality of life better than the average, which is a positive finding. A poor quality of life was indicated by $1.78 \%$ of respondents.

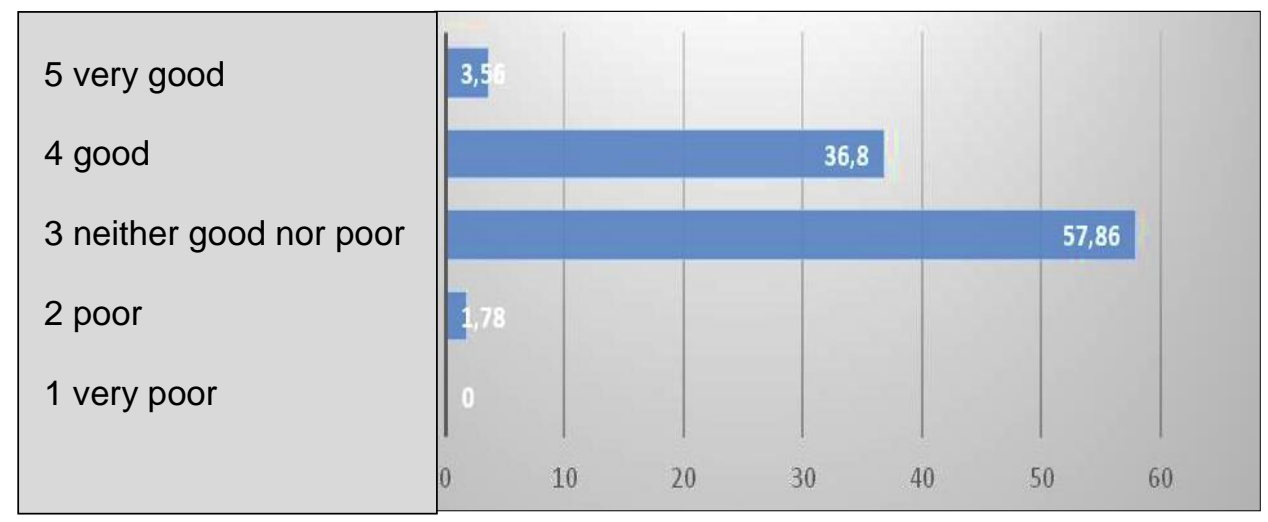

Figure 1. Perception of quality of life.

During the research, certain age-based differences occurred. The younger the respondents were; the better quality of life was indicated. The same relationship was found between the answers of older respondents - with increasing age, a higher occurrence of poor quality of life can be observed. While in the youngest group of respondents, $43.52 \%$ of them subjectively perceived their quality of life as good or very good, in the second group, it was $38.05 \%$ and in the group of the oldest respondents, it is was only $26.67 \%$. Such results could be caused by younger respondents' optimistic world view but also by other objective factors in the context of the older respondents' self-realization.

In the next step, individual fields of quality of life - physical quality of life, mental quality of life, social relationships and the environment - were evaluated based on data obtained from WHOQOL-BREF 1996 questionnaire. 


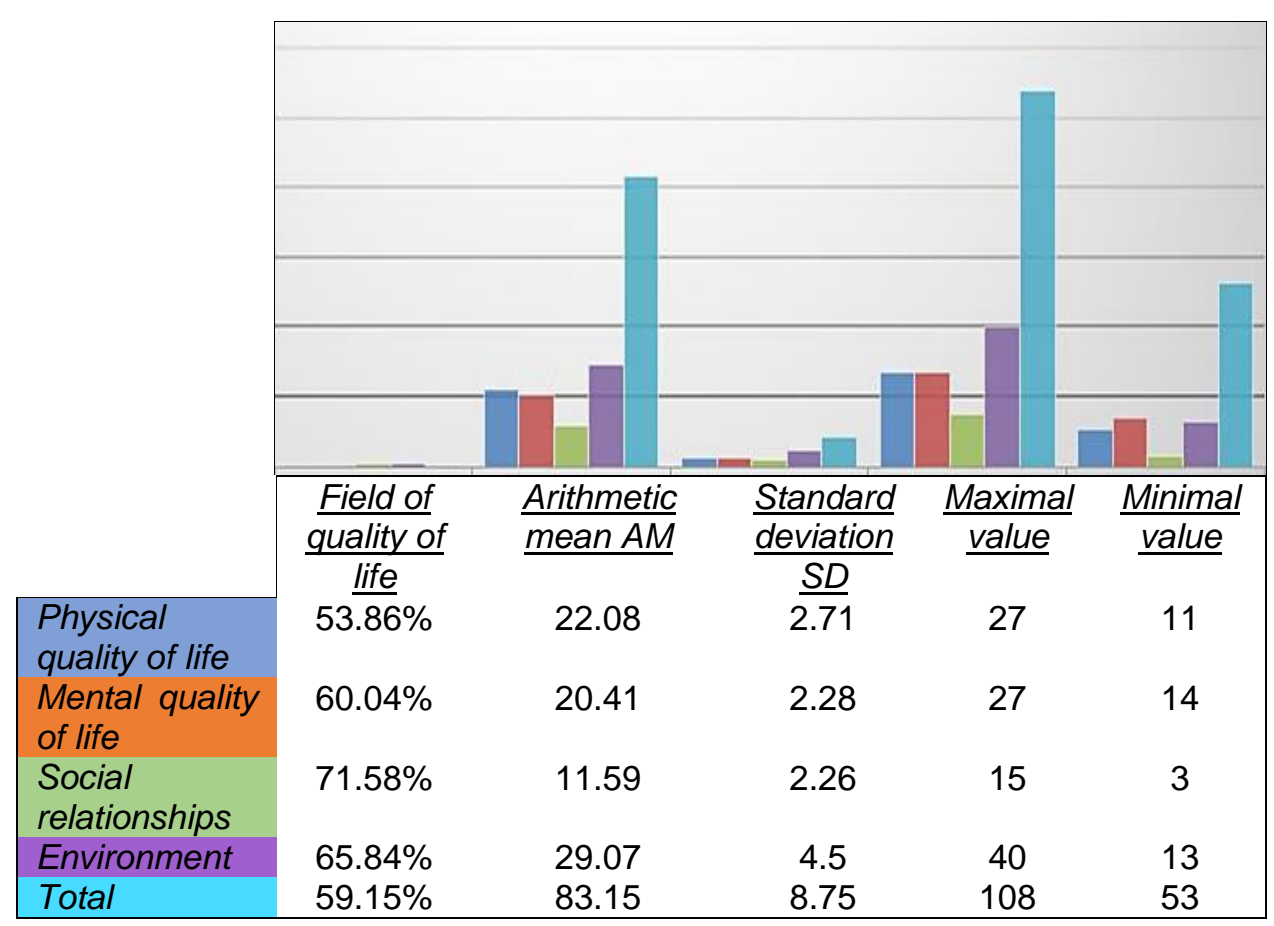

Figure 2. Fields of quality of life.

The respondents achieved the highest scores in the field of quality of social life. The average score was 11.59 ( $\mathrm{SD}=2.26)$. Social relationships were followed by the environment with the average score $29.07(\mathrm{SD}=4.5)$ and by mental quality of life with the average score 20.41 ( $S D=2.28)$. The lowest scores were achieved in the field of the physical quality of life with the average of 22.08 points $(\mathrm{SD}=2.71)$. The total average score was 83.15 points $(\mathrm{SD}=8.75)$. In the field of quality of life, no statistically significant differences were found in respondents based on their age or place of residence.

\subsection{Value orientation}

Value orientation of the respondents $(\mathrm{N}=300)$ and their scores in individual fields of value orientation are displayed in Figure 3. 


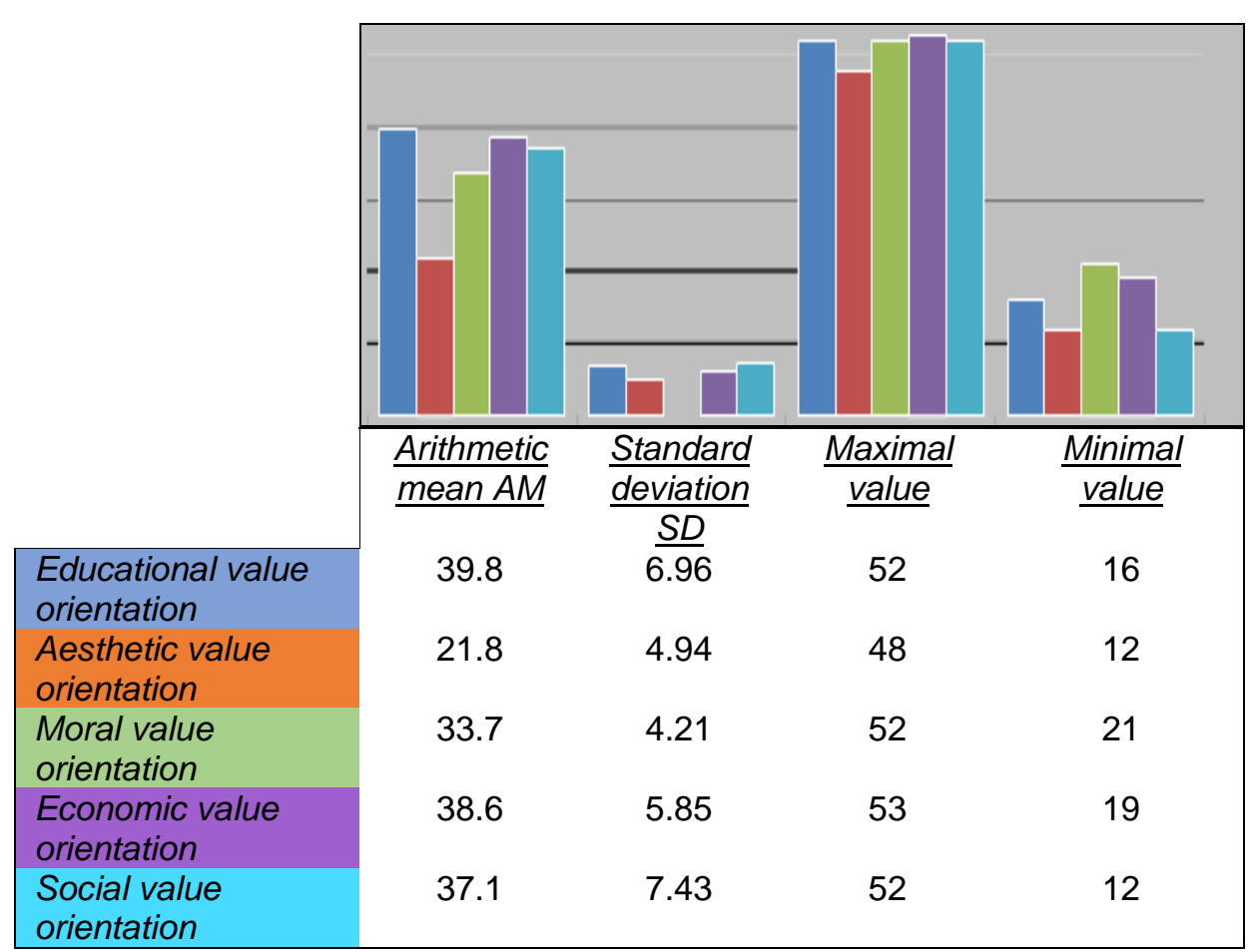

Note: $\mathrm{AM}=$ arithmetic mean; $\mathrm{SD}=$ standard deviation; $\mathrm{VO}=$ value orientation

Figure 3. Respondents' value orientation.

The highest scores were achieved by our respondents in the field of educational values - the average score was 39.8 points $(\mathrm{SD}=6.96)$, which means that, in the research sample, the highest value was assigned to education and knowledge. Education was followed by economic values with the average score of 38.6 points $(\mathrm{SD}=5.85)$. In the field of social values, the average score was 37.1 $(\mathrm{SD}=7.43)$ and with moral values it was 33.7 ( $\mathrm{SD}=4.21)$. The lowest value was assigned to moral values - 21.8 points $(\mathrm{SD}=4.94)$. It follows from the above that the respondents consider educational, economic and social values the most important, moral and aesthetic values are less appreciated. It is an interesting finding that social values are ranked third in value orientation, although in the field of quality of life, they are ranked first. This indicates certain instability in the field of social relationships and factors related to it, and vagueness as for the quality of a person's social relationships. On one hand, one part of the respondents considers values and quality of life the same as good interpersonal relationships, but on the other hand, there is a group of respondents who are not aware of the positive impact of personal relationships in the context of their value orientation. As for the age and place of residence of the respondents, no significant differences were found in their value orientation. 


\section{Acta Educationis Generalis \\ Volume 10, 2020, Issue 1}

Table 1

Respondents' ranking of the fields of quality of life and value orientation

\begin{tabular}{ll}
\hline Quality of life & \multicolumn{2}{l}{ Value orientation } \\
1. quality of social relationships & 1. educational values \\
2. quality of the environment & 2. economic values \\
3. mental quality of life & 3. social values \\
4. physical quality of life & 4. moral values \\
& 5. aesthetic values
\end{tabular}

5.3 Relations between respondents' quality of life and value orientation Kostelijk (2016) claims that if we consider values as guidelines to a higher quality of life, then the different values in the individual's value system form alternative ways to attaining a hiher quality of life. One of the goals of the research was to find out about the relations between the respondents' quality of life and value orientation. For this purpose, correlation analysis was applied.

Table 2

Correlation matrix for the fields of value orientation

\begin{tabular}{|c|c|c|c|c|c|}
\hline Value orientation & Educational & Aesthetic & Moral & Economic & Social \\
\hline Educational & & -.190 & -.227 & -.042 & -.221 \\
\hline Aesthetic & & & .421 & -.229 & -.314 \\
\hline Moral & & & & -.120 & -.296 \\
\hline Economic & & & & & -.271 \\
\hline
\end{tabular}

Similarly, correlations between the respondents' perceived quality of life and their value orientation were calculated. Spearman's rank correlation was opted for because not all the data were normally distributed.

Table 3

Correlation matrix for quality of life and value orientation

Value orientation Educational Aesthetic Moral Economic Social

Quality of life

\begin{tabular}{lrrrrr} 
Physical & .029 & -.052 & .067 & -.015 & -.018 \\
Mental & .072 & .009 & -.072 & .030 & -.056 \\
Social & -.054 & -.027 & -.033 & .010 & .079 \\
Environmental & .024 & -.046 & .000 & .000 & .008 \\
Total & .026 & -.044 & -.006 & .006 & .004 \\
\hline
\end{tabular}




\section{Acta Educationis Generalis \\ Volume 10, 2020, Issue 1}

Data in the correlation matrix show that none of the factors of value orientation correlates significantly positively or negatively with the factors of quality of life.

\section{Conclusions}

A lot of research has been done in the fields of value orientation and quality of life. Their results suggest that the factors determining the quality of individuals' life are mainly related to their personality - e.g. self-regulation, experiencing, emotional intelligence, extroversion, introversion, neuroticism, motivation, creativity, spiritual factors of the sense of life, etc. (e.g. Kováč, 2007) and external factors do not have such a big role to play. So, it follows that in the context of research on subjective perception of quality of life, researchers must distinguish between objective indicators of quality of life - income, physical health, social background, etc.; and subjective indicators of quality of life - selfsatisfaction, satisfaction with own social relationships, with own health condition, etc. (see also Lukášová, 2017). Also the research results presented in this study indicate that from the aspect of the subjective perception of the quality of life by individuals, external factors such as age or place of residence are not decisive.

The data obtained during the research show that quality of mental life correlates with educational value orientation, as well as quality of social relationships with social value orientation. As the correlation calculations neither show the direction of the relationship nor identify the cause and effect relationship, it can be stated that, as well as value orientation focusing on the values of knowledge, education and economic aspects leads to a better quality of life, a better quality of life is determined by a value orientation focused on the fields of knowledge, education and economic values. This can be considered the most important finding of the presented research.

\section{References}

Brožík, V. (2004). Hodnotenie a hodnoty. Nitra: UKF.

Eyre, L., \& Eyre, R. (2000). Jak naučit děti hodnotám. Praha: Portál.

Grác, J. (1979). Pohlady do psychológie hodnotovej orientácie mládeže. Bratislava: SPN.

Hlásna, S. et al. (2006). Úvod do pedagogiky. Nitra: Enigma.

Kováč, D. (2007). Psychológiou k metanoi. Bratislava: VEDA.

Kostelijk, E. (2016). The Influence of Values on Consumer Behaviour: The value compass. London: Routledge.

Kostelnik, M. (2006). Guiding Children's Social Development. Clifton Park, NY: Thomson Delmar Learning.

Krásna, S. (2014). Subjective understanding and individual interpretation of the life value "HEALTH" by the second-year students of lower secondary schools and of the first- and second-year students of upper secondary 


\section{Acta Educationis Generalis \\ Volume 10, 2020, Issue 1}

schools in Slovakia. Acta Technologica Dubnicae, 4(2), 1-18. https://doi.org/10.1515/atd-2015-0001

Křivohlavý, J. (2002). Psychologie nemoci. Praha: Grada Publishing.

Křivohlavý, J. (2001). Psychologie zdraví. Praha: Portál.

Kučerová, S. (1996). Človek. Hodnoty. Výchova. Prešov: ManaCon.

Lukášová, H. (2017). A study of conceptualisation of quality of life by Czech fifth-graders. Acta Technologica Dubnicae, 7(1), 59-81. https://doi.org/ 10.1515/atd-2017-0004

Mehešová, M. (2017). Social-emotional health of university students and the importance of its research. Acta Educationis Generalis, 7(2), 79-85. https://doi.org/10.1515/atd-2017-0015

Murgaš, F. (2007). Index kvality života v krajoch Slovenska a jeho indikátory. In P. Nováček (Ed.), Udržitelný rozvoj. Nové trendy a výzvy (pp. 127-139). Olomouc: Univerzita Palackého.

OECD. (2011). Compendium of OECD Well-Being Indicators. Retrieved from https://www.oecd.org/sdd/47917288.pdf

Pelikán, J. (1997). Výchova pro život. Praha: ISV.

Rokeach, M. (1979). From the individual to institutional values with special reference to the values of science. In M. Rokeach (Ed.), Understanding human values (pp. 47-70). New York, NY: Free Press.

Rosa, V. (1999). Hodnotenie kvality vzdelávania. In $K$ problematike kvality vzdelávania (pp.14-20). Bratislava: Metodické centrum.

Salbot, V., \& Kačáni, V. (2007). Hodnoty a výchova adolescentnej mládeže. In Psychologické dny 2006: "Proživáni sebe a méníciho se světa". Praha: Univerzita Karlova v Praze, Filozofická fakulta.

Schwartz, S. H. (1992). Universals in the content and structure of values: Theory and empirical tests in 20 countries. In M. Zanna (Ed.), Advances in experimental social psychology (Vol. 25, pp. 1-65). New York: Academic Press. http://dx.doi.org/10.1016/S0065-2601(08)60281-6

Vomáčková, H. (2015). Differences in the value orientation of Czech and Slovak pupils. Acta Technologica Dubnicae, 5(2), 31-50. https://doi.org/ 10.1515/atd-2015-0063

Vonkomer, J. (1991). Dotazník na zistovanie hodnotových orientácií, postojov k hodnotám a motivácie výkonu. Bratislava: Psychodiagnostika. 